https://doi.org/10.18485/iipe_postsovjet.2021.ch18

Рајко М. Буквић 1

\title{
ОД КОРЕНИЗАЦИЈЕ ДО КАЗАХИЗАЦИЈЕ: ПОТРАГА ЗА НАЦИОНАЛНИМ ИДЕНТИТЕТОМ ИЛИ УВОД У НОВЕ СУКОБЕ
}

\begin{abstract}
Ancmpaкm: У раду се разматра актуелна етничка и језичка ситуација у Казахстану, највећој земљи на простору Средње Азије и кључном руском партнеру и учеснику свих интеграционих процеса на постсовјетском пространству. Током више од два века у Руској Империји Казахстан се развио као мултиетничко и двојезичко друштво. На основу краћег историјског приказа указује се на аналогију између процеса коренизације током 1920-их и 1930-их када је Казахстан стицао своју државност у оквиру СССР-а, и процеса казахизације у времену након распада СССР-а и остваривања пуне независности. Подвлачи се да процес тражења националног идентитета у оквирима ослањања на националистичке (шовинистичке) снаге води у сукобе у оквиру самог Казахстана, као што су показали погроми националне мањине Дунгана. Као посебан аспект процеса казахизације истиче се планирани прелазак казашког језика на латинички алфабет, што ће неминовно изазвати бројне последице, међу њима и негативне. Иза тог процеса, у крајњој инстанци, налазе се не лингвистички већ политички, односно геополитички разлози. То такође води у могуће нове сукобе како унутар Казахстана тако и шире, у оквиру простора Средње Азије који има посебан значај за САД и њихове савезнике.
\end{abstract}

Кључне речи: коренизација, казахизација, Казахстан, мултиетничност, билингвизам, национални идентитет, сукоби, шовинизам.

\footnotetext{
${ }^{1}$ Рајко М. Буквић, Почасни професор, Нижегородски инжењерско-економски државни универзитет, Књагињино (Русија), r.bukvic@mail.ru
} 
у сложеним (гео)политичким процесима, који се одвијају на постсовјетском простору већ три деценије, посебно место припада Казахстану. Казахстан је члан свих интеграционих процеса бивших совјетских република, почев од Заједнице независних држава (ЗНД), у којој има статус члана-оснивача, и чији је Споразум о стварању и Протокол о Споразуму, као и Статут усвојио међу првима. ${ }^{2}$ Често је у каснијем периоду и предњачио са иницијативама и идејама о интеграцијама, посебно када је реч о Евроазијском економском простору, ОДКБ, ШОС, Царинском савезу и др. ${ }^{3}$ Тиме се он представио као својеврсни фактор стабилности и највернији руски савезник и партнер у азијском делу постсовјетског простора. ${ }^{4}$ Изгледало је да Казахстан не би могао да буде један од постсовјетских конфликтних простора, тим пре што и у оквирима тог простора не заузима периферно, већ централно место.

Највећи по пространству (2.724.900 км²), са изузетним географским положајем на азијском делу тог простора, и са великим природним минералним ресурсима, ${ }^{5}$ мада и уз наглашен проблем снабдевања

${ }^{2}$ Шире о месту и улози Казахстана у интеграционим процесима на постсовјетском простору видети у: Д. Петровић и Р. Буквић, Казахстан као чинилац интеграционих процеса на постсовјетском простору, Интеграциони процеси у Евроазији, Београд: Институт за међународну политику и привреду, 2019.

${ }^{3}$ Ш. Б. Закиева, Интеграция в Центральной Азии и Казахстан, Научная книга, Москва, 2007. стр. 10.

4 „У току 30 година Русија и Казахстан су били кључне земље-стабилизатори и иницијатори целог низа интеграција, које су, у суштини, формирале архитектуру сарадње у сфери безбедности и економије", изјавио је старији научни сарадник Сектора Централне Азије Центра постсовјетских истраживања Националног истраживачког института светске економије и међународних односа имена Ј. Примакова, кандидат историјских наука, Станислав Притчин, на конференцији „Россия и Казахстан: 30 лет стратегического партнёрства и всестороннего сотрудничества", у Москви (С. Варыханов, Общее прошлое и общее будущее, Комсомольская правда, 21 апреля 2021).

5 У питању су, пре свега, нафта и гас, али поред њих значајна је и производња урана (40\% од укупне производње у оквирима 3НД), хрома (97\%), олова (70\%), цинка (50\%), где Казахстан заузима водеће место у ЗНД. По резервама бизмута такође заузима прво место у ЗНД, велике су резерве молибдена, фосфата и кадмијума. Производе се још камени угаљ, гвоздена руда, никл, боксит и др. (Казахстан, Географический энциклопедический словарь: Географические названия, 3-е изд., гл. ред. В. М. Котляков, Москва: Большая Российская энциклопедия, 2003, стр. 306-307.) 
водом, ${ }^{6}$ Казахстан се и поред великог економског напретка, који га је сврстао међу најразвијеније државе бившег СССР, налази у својеврсној позицији тражења самосталног даљег политичког, привредног и културног развоја. Релативно малобројно становништво, посебно с обзиром на огромне просторе, свакако је један од ограничавајућих фактора не само са економског аспекта. Док по површини заузима девето место у светским оквирима, са само нешто мање од 19 милиона житеља, Казахстан је 64. у свету по бројности становништва, а по густини насељености, са седам становника на км² тек 184. Достигнути ниво економског развоја (29.800 америчких долара по становнику, 53. место у свету) и добре основе и перспективе развоја требало би да буду снажни фактори привлачења радника из других земаља, тим пре што је званично државна политика земље усмерена на побољшање миграционих аспеката.

Слика 1: Динамика становништва Казахстана 1990-2015

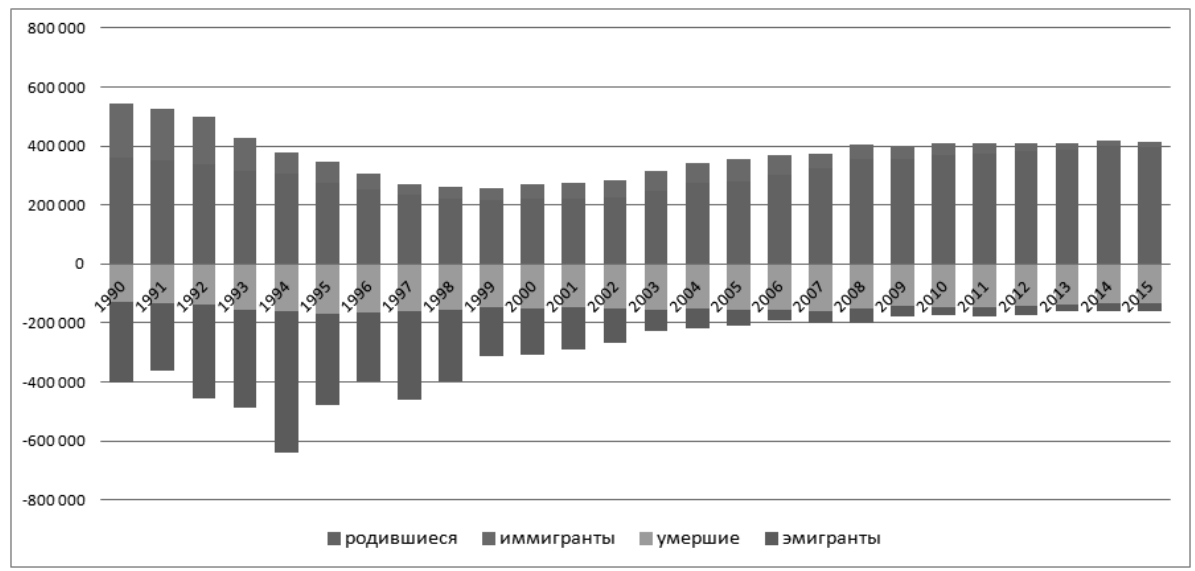

Источник: Kaiyr - собственная работа, CC BY-SA 4.0, https://commons.wikimedia.org/w/ index.php?curid=60633909

\footnotetext{
${ }^{6}$ Казахстан се убраја у континенталне земље, без обзира што има излаз на два мора (Каспијско и Аралско), будући да су оба затворена. За снабдевање водом огромних простора они немају посебан значај, за разлику од великих језера (Балхаш, Зајсин, Алакол), као и великих река (Сир-Дарја, Иртиш, Ишим), али се они сви налазе у средишњем и претежно источном делу земље. Једини изузеци су реке Урал и Емба (на казахском Жем), од којих последња раздваја европски од азијског дела Казахстана.
} 
Међутим, као што се може видети на сл. 1, за разлику од природног прираштаја који је у целом овом периоду био позитиван (чак и у годинама 1994-2001, у којима је бележено апсолутно опадање броја житеља), миграциони салдо је значајно флуктуирао и ни најмање не потврђује напред изнету претпоставку. Како је природни прираштај и у годинама опадања укупне популације био позитиван, иако и мањи него пре и после тог периода, узрок опадања броја становника била је, дакле, емиграција. У годинама после 2015, које према томе нису приказане на слици, бележи се негативни механички прираштај. Сходно статистичким подацима, у 2019. из земље се иселило више од 45 хиљада људи, што је више него у претходним годинама: 41 хиљада у 2018. и 40 хиљада у 2017. години. У последњој деценији Казахстан је напустило око 330 хиљада људи, а број усељеника на територију републике је свега 220 хиљада. ${ }^{8}$

\section{Слика 2: Национални састав становништва Казахстана почетком 2021. године}

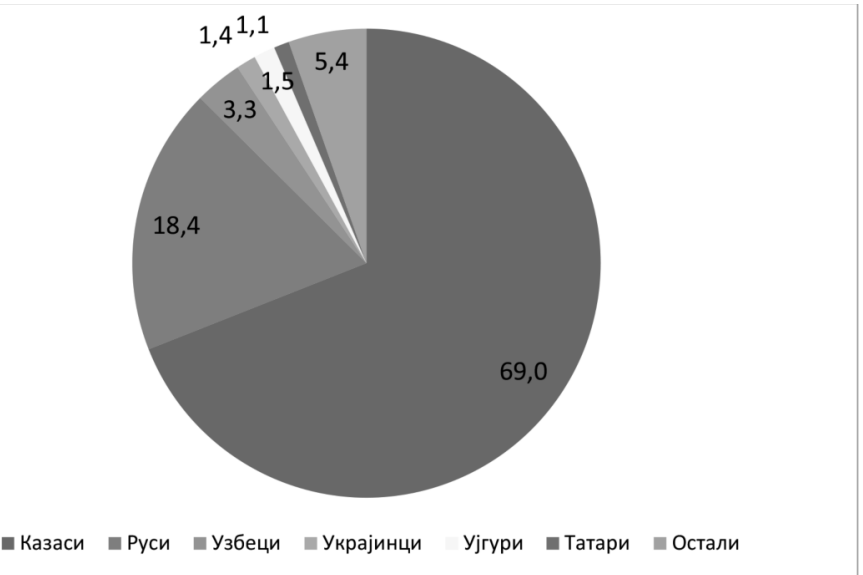

Извор: Према Численность населения Республики Казахстан по отдельным этносам на начало 2021 года. Комитет по статистике Министерства национальной экономики Республики Казахстан

\footnotetext{
7 Према подацима Комитета за статистику, број становника опао је са 16,381 у 1993. на 14,854 милиона у 2002. години, дакле за готово $10 \%$.

8 Према: Население Казахстана и статистическая информация, https://rosinfostat.ru/ naselenie-kazahstana-i-statisticheskaya-informatsiya/
} 
Данас је становништво Казахстана представљено са више од 130 етничких група, које поседују своју културу, језичку и историјску специфичност. У највеће етничке групе спадају Казаси, Руси, Украјинци, Узбеци, Немци, Татари, Ујгури, Корејци, Белоруси. ${ }^{9}$ Према подацима Комитета за статистику Министарства економије Републике Казахстан, ${ }^{10}$ почетком 2021. године Казахстан је имао 18.879 .552 становника, међу којима већину чине Казаси (13.029.227 или 69,0\%). Распоред осталих националности приказан је на слици 2, при чему смо у приказу задржали само уделе веће од 1,0\%. Нешто су мањи од те границе удели Немаца (0,9\%), Турака (0,61\%), Корејаца (0,57\%), Азербејџанаца (0,61\%), и Дунгана $(0,40 \%)$.

Као што се види на слици 2 Казаси су апсолутна већина становништва, нешто преко две трећине, и с руским становништвом (нешто мање од петине) чине готово девет десетина укупног становништва Казахстана. Стога би се могло условно рећи да је Казахстан претежно двонационална држава, без обзира на постојање изузетно великог броја етничких група. А одатле, по логици ствари, следи и да је Казахстан двојезичка држава, што је и формално уређено на нивоу правне регулативе. ${ }^{11}$ Ово потоње, међутим, захтева мало детаљнију елаборацију, и то ће бити предмет наредног излагања.

\footnotetext{
${ }^{9}$ К. Б. Аманжолова, Проблемы казахско-русского двуязычия и их интерпретация в трудах современных лингвистов, Ученые записки Новгородского государственного университета имени Ярослава Мудрого, 2019, № 7 (25), с. 3.

10 Численность населения Республики Казахстан по отдельным этносам на начало 2021 года, Комитет по статистике Министерства национальной экономики Республики Казахстан.

11 у Уставу Републике Казахстан утврђен је статус казашког језика као државног (члан 7, став 1), док је статус руског одређен на следећи начин: „У државнним организацијама и органима локалног самоуправљања упоредо с казашким официјелно се користи руски језик" (члан 7, став 2). На тај начин, на законодавном нивоу официјелно је одређена двојезичност.
} 
Слика 3: Удео и територијални распоред европског становништва у Казахстану у 2020. години

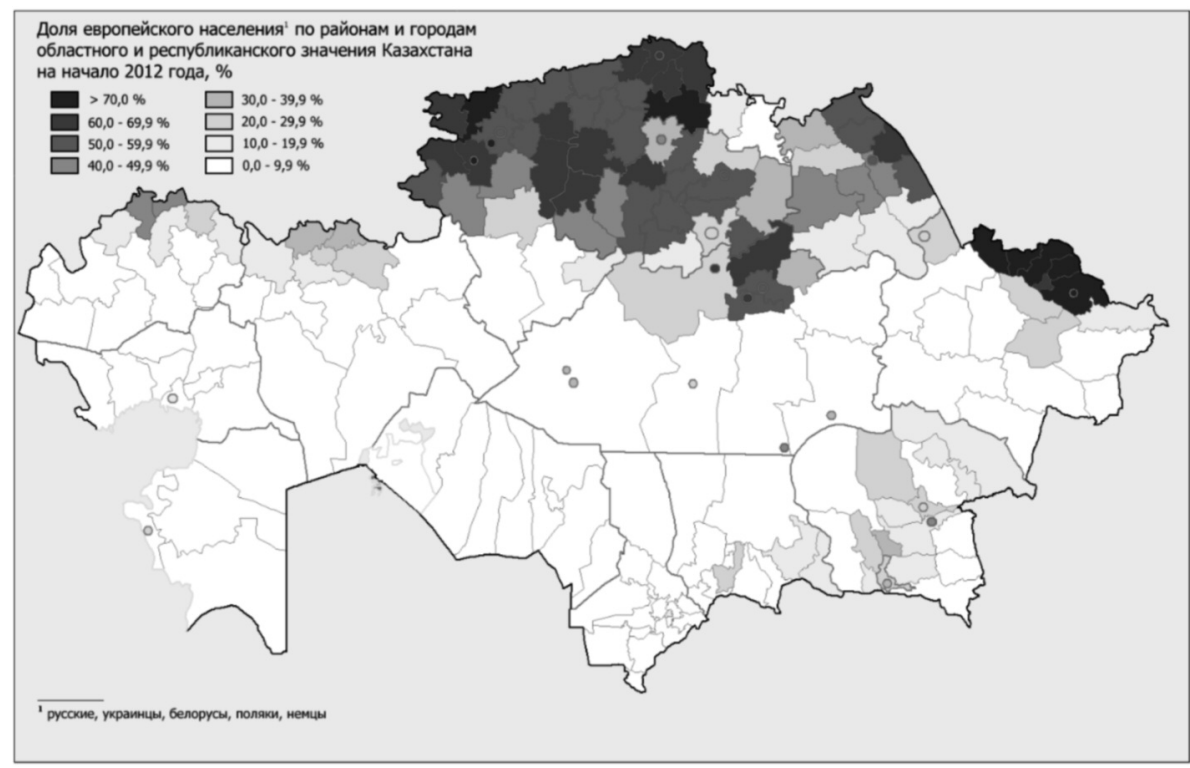

Извор: Европейское население в Казахстане в 2020 году

Погледајмо најпре слику 3, на којој су представљени удели становника европских националности (Руси, Украјинци, Белоруси, Пољаци и Немци) у укупном становништву Казахстана у 2020. години, и њихов територијални распоред. Као што се види, они су концентрисани у северним и североисточним деловима земље. У оквиру тога, највећу бројност и највећи удео у становништву Руси имају у Северно-Казахстанској области (око 268.000 и 49,2\%), Костанајској области (близу 351.000 и 40,6\%), ИсточноКазахстанској области (близу 479.000 и 35,1\%), Карагандинској области (око 477.000 и 34,7\%), Павлодарској области (око 259.000 и 34,5\%), Акмолинској области (око 237.000 и 32,3\%), као и у нешто насељенијој Алматинској области (око 268.000 и 12,9\%), односно доскорашњем главном граду Алма-Ати (близу 464.000 и 23,5\%). ${ }^{12}$ Концентрација

\footnotetext{
12 Численность населения Республики Казахстан по отдельным этносам на начало 2021 года. Комитет по статистике Министерства национальной экономики Республики
} 
европеидног, пре свега руског становништва у овим областима могла би се сматрати, бар једним делом, као нормално мешање становништва између двеју држава, како пре успостављања границе међу њима, тако и после тога. ${ }^{13}$ Међутим, у случају Казахстана постојали су и други разлози, који су вероватно били и значајнији.

\section{Присаједињење Руској Империји}

Територије обухваћене данашњим Казахстаном биле су, наиме, део Руске Империје нешто више од два века. Прва казашка држава формирана је на овим територијама, на којима су вековима живели номади - Усуни и Хуни, Туркијци, Арапи, Огузи, Монголо-Татари, за време кана Касима, који је владао у периоду 1511-1523, да би за време Хак-Назара (1538-1580) била формирана три родовско-племенска савеза: Старији жуз (Семиречје), Средњи жуз (Централни Казахстан) и Млађи жуз (Западни Казахстан)14. Према уобичајеном тумачењу, крајем 17. и почетком 18. века казашки канати били су циљ разорних најезди Џунгара, и у недостатку сопствене јаке државне структуре они су заштиту потражили и нашли у Руској Империји. Кан Млађег жуза Абулхаир заклео се 1731. на верност руском императору

Казахстан. У односу на стање почетком 2019. године, које смо фиксирали приликом припреме претходног рада (Д. Петровић и Р. Буквић, Казахстан као чинилац интеграционих процеса на постсовјетском простору, Интеграциони процеси у Евроазији, Београд: Институт за међународну политику и привреду, 2019, видети стр. 196) у свим наведеним областима опао је и апсолутан број и удео руског становништва.

${ }^{13}$ Заправо, како се наводи у Великој савременој политичкој енциклопедији (Большая актуальная политическая энциклопедия, Москва: Эксмо, 2009, стр. 118): «Северни рејони савременог Казахстана никада нису били део традиционалног живљења Казаха, њих су освојили руски насељеници и они су историјски део Русије». У том смислу ситуација с мешовитим националним становништвом у ствари се може посматрати као одраз у огледалу уобичајеног схватања.

${ }^{14}$ Од каз. жүз, јüz, زؤج- «савез». У погледу времена формирања ових савеза постоји несагласност руских и казашких историчара - док први сматрају да су они настали у 17. веку, други њихов настанак смештају на почетак 18. века. Треба нагласити да постоје и другачија мишљења, која њихову појаву померају и на више векова у прошлост. 
у замену за војну помоћ и заштиту. За њим су убрзо пошли и канови друга два жуза: 1734. исто је учинио кан Средњег жуза Семеке, а 1748. и кан Старијег жуза Абилај, при чему је Абилај 1756. постао и кинески поданик. ${ }^{15}$

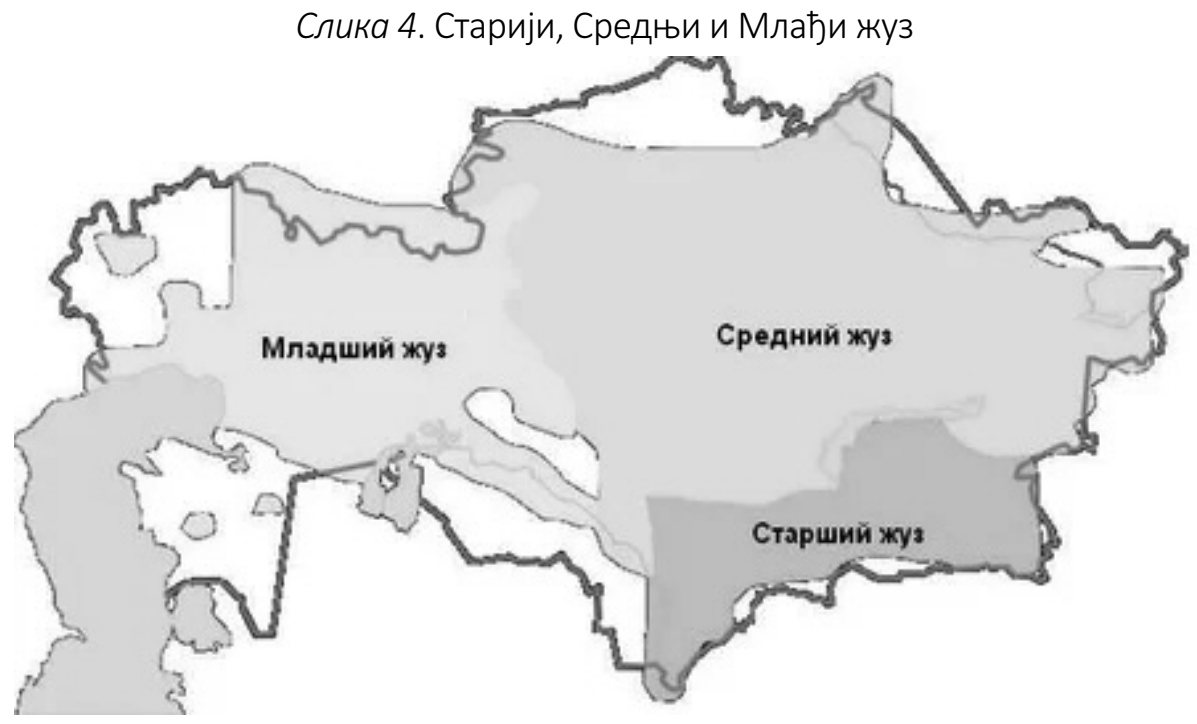

У сваком случају, дакле, сва три жуза заједно са територијама које нису имале стално становништво (видети сл. 4) нашла су се добровољно у саставу Руске Империје до средине 18. века, иако је ситуација у Старијем жузу све до половине наредног века остајала нестабилном, будући да се део ових земаља налазио под кокандском влашћу. Заједнички живот у оквиру Империје, а затим СССР-а, имао је далекосежне културне и економске последице. Међу њима се издвајају последице реформе

\footnotetext{
15 Чињеницу да је у састав Руске Империје прво ушао Млађи жуз, који је најудаљенији од Џунгара, Болат Султанов објашњава као резултат тога што је Млађи жуз био циљ напада и бухарских владара, Хивског и Кокандског каната, туркменских племена, као и сибирских и јаицких козака и Башкира и волшких Калмика. Након још једног од крупних напада Џунгара 1723, казаси су били принуђени на повлачење на запад, пре свега Млађи жуз, иако је управо он под вођством Абулхаира нанео неколико пораза Џунгарима. (Как присоединялся Казахстан к России на самом деле? Султанов, ИА-Центр, 27 декабря 2017).
} 
(ревизије) Сибира, покренуте у време генерал-губернаторства (1819-1821) Михаила Михајловича Сперанског, истакнутог руског државног делатника, оснивача правне науке и реформатора и спроведене у наредним годинама. ${ }^{16}$ На основу реформи Сперанског почела је трансформација номадског становништва у земљораднике, што је у наредним деценијама довело и до почетака образовања а затим крајем века и до формирања првих слојева казашке интелигенције.

Руси и други неказашки народи почели су да насељавају територије данашњег Казахстана непосредно по присаједињењу Руској Империји. Први насељеници у 18. и првој половини 19. века били су козаци. Овде су биле распоређене три козачке армије: Уралска (Јаицка), Семиреченска и Сибирска. Стварање тврђава, шанчева, граничних утврђења било је почетак дуготрајног процеса формирања сталног становништва. Од 70-их година 19. века почело је насељавање сељака из европског дела Империје, што је повезано са укидањем крепосног права. У прво време власти су покушавале да спрече овај процес, али су биле немоћне и од 1880-их определиле су се да га регулишу. ${ }^{17}$ Према подацима из више извора Н. В. Алексејенко је дошао до статистике према којој се у периоду 1870-96 у Казахстан населило 407.265 људи, од чега из европске Русије 277.348, или 68,1\%. ${ }^{18}$

\section{Казахстан у Совјетском Савезу}

Казашка државност остварена је у току совјетског периода, иако је он и даље предмет различитих оцена, како с једне тако и с друге стране

\footnotetext{
${ }^{16}$ Сперански је лично или при његовом руководству припремио више пројеката, међу осталим «Учреждение для управления Сибирских губерний» и «Устав о сибирских киргизах», који се односио на присаједињене територије казашких жуза и којим је канска власт била ликвидирана. Видети: В. А. Томсинов, Сперанский, Москва: Молодая гвардия, 2006, стр. 327. и даље.

${ }^{17}$ Н. В. Алексеенко, Население дореволюционного Казахстана (численность, размещение, состав, 1870-1914 г2.), Алма-Ата: Издательство «НАУКА» Казахской ССР, 1981, с. 52. и даље.

${ }^{18} \mathrm{H}$. В. Алексеенко, Население дореволюционного Казахстана (численность, размещение, состав, 1870-1914 гг.), Алма-Ата: Издательство «НАУКА» Казахской CCP, 1981, c. 65.
} 
границе, при чему се на крају испоставило да се до резултата дошло неправолинијским путем, па чак у извесној мери супротно почетним интенцијама. Наиме, земље Старијег жуза укључене су 30. априла 1918. у Туркестанску АССР (Аутономну Совјетску Социјалистичку Републику), која је постојала до 27. октобра 1924, а земље Средњег и Млађег жуза од 26. августа 1920. у Киргиску АССР, са Оренбургом као главним градом, обе дакле у оквиру РСФСР. Како су се и зашто Оренбург и Оренбуршка губернија нашли у Киргиској АССР заиста је недовољно јасно, будући да је реч о територији која је припадала Руској Империји пре присаједињења сва три казашка жуза, а сама Оренбуршка губернија оформљена је још 1744. године, ${ }^{19}$ и може се можда објаснити разлозима тактичке природе нових власти у борби против покрета Алаш и Алашке аутономије (каз. Алаш Мұхтарияты), која је на челу са председником владе Алиханом Букејхановим постојала од 5-13 (18-26) децембра 1917. до 5. марта 1920, када ју је ликвидирао Војно-револуционарни комитет по управљању Киргиским крајем. Особите недоумице код неупућених може изазвати назив Киргиска, што сугерише да бољшевици нису познавали народе који су живели на овим територијама, а што се иначе може пронаћи понекад у нешто популарнијим текстовима. Једно од могућих објашњења, ипак, мало је другачије. Под етнонимом киргизи (киргизи или киргиз-кајсаки), као општим појмом, подразумевали су се номади који су живели на великој територији од Каспија до Алтаја, јужно од Оренбурга, а међу њима је био само један род под именом „казах“, на територији између језера Зајсан и Алакол, на крајњем истоку данашњег Казахстана, сасвим при граници са кином. $^{20}$ Оваквом објашњењу у прилог би могао да иде и попис становништва у Империји 1897, у коме су (данашњи) Киргизи и Казаси били обухваћени заједничким именом Киргиз-Кајсаки. ${ }^{21}$ Према првом попису

${ }^{19} \mathrm{C}$. Тархов, Изменение административно-территориального деления России в XIII-XX вв., Логос, 2005, № 1 (46), , с. 66.

20 Према: Речь пойдёт о истории ПОЯВЛЕНИЯ государства „Казахстан“ и т.н. „казахов“... Наравно, мора се нагласити да ово схватање није нити може бити коначна и неопозива истина.

21 Забуна око имена Киргизи и Казахи (тада Казаки) потиче још с почетка 18. века, и њу је разматрао академик Бартолд у свом есеју о Киргизима (видети: В. В. Бартольд, Киргизы (исторический очерк), Киргосиздат, Фрунзе, 1927, стр. 46. и даље). 
1897. години Руса је било 454.402 и чинили су око 11\% становништва савремене територије Казахстана, а Казаха 3.392 .751 или 81,7\%.

У годинама 1924-1925. извршено је у СССР-у национално-државно разграничавање, у оквиру ког је Киргиска АССР територијално увећана за

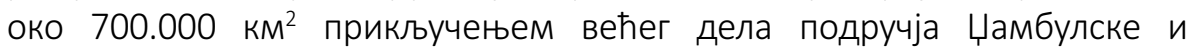
Сирдарјинске области. ${ }^{22}$ Након тога, $\vee$ конгрес Совјета републике преименовао је Киргиску АССР у Казакску АССР, која је постојала од 15. јуна 1925. до 5. децембра 1936. Административни центар био је на почетку КзилОрда (касније преименована у: Кизилорда), а од 1929. Алма-Ата (основана 1854. као Укрепление Верное, касније град Верный), која је била и главни град независног Казахстана до преношења престонице у Астану (која је недавно променила име у Нур-Султан). Најзад, Казакска АССР била је 1936. најпре преименована у Казахску АССР, а затим проглашена за савезну републику - Казахску (Казашку) Совјетску Социјалистичку Републику.

Погледајмо како се оцењује развој Казахстана у току 20. века, од стварања СССР-а до стицања независности. ${ }^{23}$ У време совјетске власти Казахстан је од заостале аграрне провинције трансформисан у републику са развијеном примарном и прерађивачком индустријом. Већ до 1941. у току процеса индустријализације целог СССР-а подигнуто је у Казахстану око 200 крупних индустријских предузећа (између осталих Чимкентски /Шимкентски/ и Балхашки завод, у Караганди је створена једна од највећих у СССР угљених база) и реконструисан низ старих предузећа, проширена је железничка мрежа (1931. пуштена је у сталну експлоатацију Туркестанско-сибирска железничка пруга, Турксиб, дужине 1,4 хиљаде км. Даљи подстрек привредном развоју уследио је у годинама Отаџбинског рата (1941-1945), када је на територију Казахстана евакуисано више од 140 великих индустријских предузећа. У пољопривреди је била спроведена колективизација, која је до 1937. обухватила у оквиру колхоза 97,5\% сеоских газдинстава. Међутим, пољопривредна политика донела је много

${ }^{22}$ Советский Союз. Республики Закавказья. Республики Средней Азии. Казахстан, отв. ред. Т. А. Жданко, (Страны и народы. Издание в 20-ти томах), Москва: Мысль, 1984, стр. 328.

${ }^{23}$ Највећи део наредних излагања заснован је на одредници Казахстан, одељак Советский Казахстан (1920-91) у: Большая российская энциклопедия - электронная версия, 2004. 
негативних последица, почев од прве мере совјетске власти у Казахстану конфискације, спроведене 1928, којом је руководио чувени Шаја Голошћокин (Филипп Исаевич Голощёкин, право име Шая Ицикович). ${ }^{24}$

Упоредо са привредним одвијали су се и други процеси. Значајни резултати остварени су на културном и научном плану: отворене су високе школе и научне установе, 1932. је створена база, а 1938. филијала АН СССР. Израсла је нова интелигенција, на светском нивоу постали су познати казахстански научници: геолог К. И. Сатпајев, филолог Н. Т. Сауранбајев, правник С. В. Јушков, микробиолог И. Г. Галузо, астрофизичар Г. А. Тихов, хемичар А. Б. Бектуров и др. У оквирима СССР-а славу су стекли романи М. Ауезова и музика А. К. Жубанова. За време рата интензивно су развијана научна, посебно одбрамбена, истраживања, а 1945. основана је АН Казахске ССР. Међутим, упоредо са овим свакако позитивним процесима било је и другачијих. Тако је Казахстан, као и друге несловенске савезне и аутономне републике, био захваћен процесом латинизације. ${ }^{25}$ Пројектом који је иницирао тадашњи министар просвете А. Луначарски, и чији је крајњи циљ било превођење руског алфабета на латиницу, замењено је арапско писмо које је у казашком језику коришћено готово хиљаду година и започето, у име идеолошких циљева, експериментисање са писмима не само малих народа (од којих неки у то време и нису имали своје писмо), већ и народа са дугом историјом и традицијом. Тако су, после само десетак година, ти исти језици прешли на ћирилично писмо, да би крајем 20. века неки од њих поново увели латинско писмо, а такав исти пројекат припремљен је и за казашки језик и у току су припреме за његово реализовање, које треба да се заврши до 2025.

\section{Национално питање и коренизација}

Процес латинизације алфабета неруских (и несловенских) језика преплитао се са процесом коренизације, који су бољшевици покренули

24 Током седам и по година (од октобра 1925. до фебруара 1933) он је био на дужности одговорног секретара Казахстанског крајкома ВКП(б), фактички владар Републике Казахстан. За то време иселило се преко милион људи, од тога преко 600 хиљада неповратно, а од глади је умрло око милион.

${ }^{25}$ Видети детаљније у: Р. Буквић, Совјетски пројекат латинизације руског алфабета, Нова српска политичка мисао, 24. август 2013. 
одмах након револуције и преузимања власти, у складу са својом националном политиком. ${ }^{26}$ Према званичном тумачењу, коренизација је политичка и културна кампања совјетских власти у националном питању током 1920-их и почетка 1930-их година, која је као циљ имала ублажавање противречности између централне власти и становништва националних република, односно аутономија у оквиру СССР-а и Русије. Спроводила се кроз припрему и промовисање на руководеће положаје представника националних мањина, стварање национално-територијалних аутономија, увођење језика националних мањина у привреду и образовање, подстицање издавања средстава масовног информисања на локалним језицима. Другим речима, била је то политика која је у знатно већој мери подржавала културу, језик, елите и територије националних мањина него већинског, руског народа. ${ }^{27}$ Сходно општеприхваћеном мишљењу, коренизација је спровођена негде до краја 1930-их, ${ }^{28}$ али би се, вероватно, такво омеђивање бар донекле могло сматрати спорним, и питати да ли је заправо процес коренизације икад напуштен. При томе, не треба негирати факте да се у одређеним периодима после 1930-их одвијао и супротан процес, процес русификације, без обзира на форме у којима се он манифестовао. Уобичајено тумачење процеса коренизације прилично је поједностављено - наводно бољшевици су на тај начин (односно, уопште својом националном политиком) покушавали да придобију неруске народе у борби против супарника и касније за своје пројекте изградње новог друштва. ${ }^{29}$

${ }^{26}$ Формално, политика коренизације промовисана је на 12. конгресу РКП(б) 1923. године, у реферату који је поднео Ј. В. Стаљин и у резолуцијама и одлукама које је донео Конгрес. (Видети: Двенадиатый съезд РКП(б). Стенографический отчёт, Москва: Политиздат, 1968, стр. 479-495, 691-697).

${ }^{27}$ Видети: Т. Мартин, Империя «положительной деятельности». Нации и национализм в СССР, 1923-1939, Москва: РОССПЭН и Фонд «Президентский центр Б. Н. Ельцина», 2011.

${ }^{28}$ На Википедији се у процес коренизације убрајају и Беријине националне реформе током кратког периода март-јун 1953. године.

${ }^{29}$ Коренизација је данас једна од широко заступљених тема у руској и постсовјетској средини, како у научној тако и у популарнијој продукцији. Однос према том процесу и његове оцене доста су неуједначени, и стога би можда било корисно упутити на његово сагледавање од стране једног истраживача који не припада том постсовјетском простору: Лю Сяньчжун. Плюсы и минусы политики «коренизации» СССР в 1920 е годы, Ойкумена, 2014, № 1. 
Можда би се бољшевицима, рећи ће неко, могле приписати и племенитије намере, наиме жеља за праведнијим решавањем националног питања, посебно с обзиром на то да су државу коју су срушили сматрали за „тамницу народа“. ${ }^{30}$ Јер, ова Лењинова оцена била је касније понављана, не само у његовим делима, ${ }^{31}$ и ушла је у програмске документе бољшевичке партије, па и саме совјетске власти у решавању националног питања. Ови Лењинови ставови, у исто време аргументи у полемици с идеолошким противницима, заслужују да буду наведени. Особитост Русије, по Лењину, састоји се у следећем: 1. „инородци“ (који у целини чине већину становништва - 57\%) насељавају управо крајине; 2. угњетавање тих инородаца знатно је снажније него у суседним државама (и то не само у европским); 3. у целом низу случајева угњетене народности које живе на крајинама имају своје сроднике с друге стране границе, који имају више националне независности (довољно је сетити се бар западне и јужне границе државе - Финаца, Швеђана, Пољака, Украјинаца, Румуна); 4. развитак капитализма и општи ниво културе неретко је виши код „инородачких“ крајина, него у центру државе. ${ }^{32}$

Међутим, како су показали Н. и В. Михајлови, ${ }^{33}$ користећи поред статистичких података Пописа 1897. и малопознати реферат В. Власова „Центар Русије и њене крајине у културно-економском односу“, прочитан

\footnotetext{
${ }^{30}$ матра се да је овај, веома често коришћен израз настао на основу изузетно популарне књиге Маркиза де Кистина La Russie en 1839, која је објављивана, најчешће у скраћеном издању, под различитим насловима. У руском преводу објављеном 1990. (А. де. Кюстин, Николаевская Россия, Москва: Политиздат, 1990) одговарајућа места налазе се у главама XI (стр. 157) XVI (стр. 203). У смислу тамнице неруских народа термин је први користио Лењин у рукопису - пројекту говора с којим је требало да иступи бољшевички депутат Г. И. Петровски у IV Државној думи. (В. И. Ленин, К вопросу о национальной политике, Полное собрание сочинений, Том 25, Москва: Издательство политической литературы, 1980, с. 66).

${ }^{31}$ Пре свега имамо у виду његов обиман чланак О праву нација на самоопредељење из исте 1914. године. (В. И. Ленин, О праве наций на самоопределение, Полное собрание сочинений, Том 25, Москва: Издательство политической литературы, 1980, c. 255-320).

${ }^{32}$ В. И. Ленин, О праве наций на самоопределение, Полное собрание сочинений, Том 25, Москва: Издательство политической литературы, 1980, с. 2

${ }^{33}$ Н. В. Михайлова и В. А. Михайлов, Была ли царская Россия «тюрьмой народов»?, Свободная мысль, 2013, № 6.
} 
19. фебруара 1906. године на општем собрању Руског друштва у Варшави, Ленин је у наведеном раду дао очито искварену, идеологизовану оцену карактера државности царске Русије, називајући је „тамницом народа̂“, па чак и „најзаосталијом земљом, чак заосталијом од Кине“. Супротно Лењину, аргументи доказују да је „царска власт водила проверену националну политику", да је "био створен уредан систем односа између центра и крајина, имперске власти и локалних заједница".Из свих изведених закључака они сумирају да је „циљ Лењинове оцене - чисто политички: разбуктавање класне борбе у име револуције“.34

Шта рећи, чак и ако бисмо прихватили да су бољшевици били у праву кад је реч о националном питању, без обзира на наведено, њихово тадашње незнање (или површно знање) и дилетантизам су се и више него испољили, у многим акцијама и кампањама, али и у апсолутно неодговарајућим „цртањима“ међунационалних граница. Уосталом, резултати бољшевичке националне политике показали су се као катастрофални, при томе не само у правој експлозији национализама и међунационалне мржње у време распада СССР-а (слободна је и потпуно адекватна паралела и са СФР Југославијом). А шта рећи за један знатно каснији догађај, за превођење Крима из Русије у Украјину 1954. године. Ако бисмо и могли да прихватимо да су њиховом националном политиком руководиле племените намере, могло би се закључити оним што је већ давно речено - „Пут за пакао поплочан је добрим намерама“. Што се тиче теме која се у овом тексту разматра, лењинска национална политика такође је имала погубне последице. Наиме, после освајања и учвршћења власти, бољшевици су националну политику спроводили у складу с изложеним (нетачним и исквареним, идеологизованим) начелима, увек у корист националних република, тј. крајина и инородаца, желећи да тиме придобије њихове елите за нову, совјетску државу. Пошто се киргиска (казашка) Алаш-Орда у децембру 1919. потчинила совјетској власти, као својеврсну награду Киргизи (Казаси) су добили земље Уралских (Јаицких) козака, па чак и Оренбуржје, али је оно касније (1925. године) враћено у састав РСФСР. Остале козачке земље на данашњем северу Казахстана остале су у његовом саставу.

\footnotetext{
${ }^{34}$ Н. В. Михайлова и В. А. Михайлов, Была ли царская Россия «тюрьмой народов»?, Свободная мысль, 2013, № 6, стр. 155, 156.
} 
Бурни демографски процеси преплитали су се са социјалним, и не могу бити једнозначно оцењени. Најпре су у оквиру земљишно-водних реформи 1921-1922. велике површине земљишта одузете од досељеника и враћене староседеоцима. ${ }^{35}$ Индустријски развој био је праћен формирањем нове радничке класе, у којој је значајну улогу имало и домаће становништво. Крајем 1930-их и у току Отаџбинског рата Казахстан је био велико имиграционо подручје, између осталог овамо су досељавани депортовани народи (поволшки Немци, Кримски Татари, Ингуши, Чечени, Калмици и др.). Тиме је појачан вишеетнички састав становништва, што наравно само по себи носи одређене културолошке, економске и друге последице. Национални састав становништва Казахстана сходно пописима становништва у СССР и независном Казахстану приказан је у табели 1.

\footnotetext{
35 Трансформације спроведене 1921-1922. у Туркестанској АССР и Киргиској АССР и 1925-1929. после национално-државног разграничења и свим поново образованим републикама и Казакској АССР, усмерене на прерасподелу земљишно-водних ресурса. Земља која је раније дата, војска сибирских и уралских козака, као и конфискована газдинства, предати су 1921-1922. староседеоцима (у Казахстану више од 470 хиљада ха). У годинама 1925-1929. у Казакској АССР конфисковано и прераспредељено око 2,6 млн. ха, а конфискацији и прераспредели подвргнута је и стока. (Земельно-водные реформы, у: Большая российская энциклопедия электронная версия, 2004).
} 


\begin{tabular}{|c|c|c|c|c|c|c|c|c|c|c|c|c|c|c|c|c|c|}
\hline 耪 & 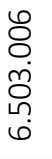 & & 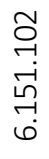 & & $\begin{array}{l}\text { f } \\
\infty \\
\text { ळे } \\
\text { m. } \\
\sigma\end{array}$ & & 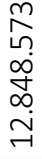 & & 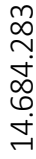 & & & & & & $\begin{array}{l}\text { ने } \\
\text { ஸุ } \\
\text { ஜे } \\
8 \\
\dot{\varphi}\end{array}$ & & 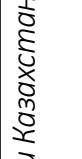 \\
\hline 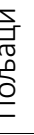 & $\frac{\widetilde{N}}{\stackrel{m}{m}}$ & 궁 & $\begin{array}{l}\text { oे } \\
\infty \\
\dot{\forall} \\
\text { ம் }\end{array}$ & $\begin{array}{l}\sigma \\
\sigma^{\prime}\end{array}$ & 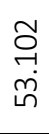 & $\begin{array}{l}6 \\
0\end{array}$ & $\begin{array}{l}\stackrel{\omega}{m} \\
m \\
\dot{\sigma}\end{array}$ & $\stackrel{\text { 우 }}{0}$ & $\begin{array}{l}\stackrel{\oplus}{m} \\
\underset{\sigma}{\sigma}\end{array}$ & & & & & $\begin{array}{l}m \\
0\end{array}$ & 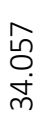 & $\widetilde{N}$ & \\
\hline 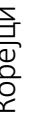 & $\stackrel{\sim}{\sim}$ & O̊. & 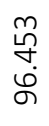 & $\stackrel{\varphi}{\rightarrow}$ & $\begin{array}{l}\sigma \\
\stackrel{-}{0} \\
\stackrel{+}{N}\end{array}$ & $\stackrel{\infty}{\infty}$ & \begin{tabular}{l}
$\infty$ \\
\multirow{0}{0}{} \\
$\infty$ \\
$\infty$
\end{tabular} & $\begin{array}{l}6 \\
0 \\
0\end{array}$ & $\begin{array}{l}\text { के } \\
\text { ने } \\
\text { ने }\end{array}$ & & & & & $\hat{o}$ & 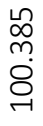 & $\begin{array}{l}6 \\
0 \\
0\end{array}$ & \\
\hline$\frac{\substack{a \\
\frac{2}{2}}}{\lambda}$ & 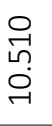 & $\underset{\sigma}{\sim}$ & $\begin{array}{l}\text { Oे } \\
\text { ஸे } \\
\text { ஸे }\end{array}$ & $\begin{array}{l}0 \\
0 \\
0\end{array}$ & 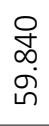 & $\begin{array}{l}6 \\
0\end{array}$ & 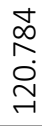 & $\begin{array}{l}\sigma \\
\sigma\end{array}$ & 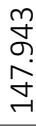 & & & & & $\begin{array}{l}\underset{-}{+} \\
\text {. }\end{array}$ & $\begin{array}{l}\stackrel{m}{\rightarrow} \\
\underset{\dot{D}}{\stackrel{N}{N}}\end{array}$ & $\stackrel{+}{+}$ & \\
\hline$\frac{\sqrt{2}}{\frac{2}{\sigma o}}$ & \begin{tabular}{l}
\multirow{F}{*}{} \\
$\stackrel{\infty}{0}$
\end{tabular} & $\underset{f}{\sim}$ & 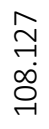 & $\stackrel{\infty}{\rightarrow}$ & $\begin{array}{l}\text { Oे } \\
\infty \\
\text { - } \\
\text { } \\
\text { - }\end{array}$ & $\stackrel{-1}{\sim}$ & $\begin{array}{l}\text { D } \\
\infty \\
\text { - } \\
\stackrel{\infty}{\sim}\end{array}$ & $\stackrel{\sim}{\sim}$ & 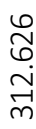 & $\sim$ & & & & $\hat{f}$ & 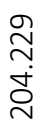 & $\stackrel{m}{\rightarrow}$ & \\
\hline$\sum_{\substack{I \\
I}}$ & $\begin{array}{l}\text { જે } \\
\text { ને } \\
\text { تં }\end{array}$ & $\stackrel{\infty}{0}^{\infty}$ & $\begin{array}{l}\text { ஸे } \\
\text { न่ }\end{array}$ & $\stackrel{\text { ก }}{\digamma}$ & $\begin{array}{l}\overrightarrow{\hat{n}} \\
\hat{\sigma} \\
\text { ஸ̂ં }\end{array}$ & $\stackrel{-1}{N}$ & $\begin{array}{l}\text { م } \\
\text { bे } \\
\text { ஸे } \\
\infty\end{array}$ & 'ص & $\begin{array}{l}\text { 오 } \\
\text { ণे } \\
\text { ᄋ̊ }\end{array}$ & & & & & 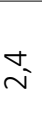 & $\begin{array}{l}\text { o } \\
+ \\
\infty \\
\infty \\
ન \\
-1\end{array}$ & $\underset{-}{\rightarrow}$ & \\
\hline 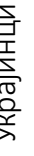 & $\begin{array}{l}\underset{1}{\infty} \\
\infty \\
\varnothing \\
\infty\end{array}$ & $\stackrel{\sim}{\tilde{n}}$ & 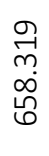 & $\hat{\circ}$ & $\begin{array}{l}\stackrel{ }{m} \\
\stackrel{\sim}{\sim} \\
\stackrel{n}{N}\end{array}$ & $\stackrel{\sim}{\infty}$ & $\begin{array}{l}\infty \\
\text { ñ } \\
\text { ஸ் } \\
\text { ñ }\end{array}$ & $\stackrel{N}{N}$ & 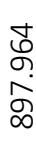 & 6 & & & & $\hat{\bar{m}}$ & $\begin{array}{l}\stackrel{\text { }}{O} \\
\text { m} \\
\stackrel{m}{m}\end{array}$ & $\stackrel{ }{\sim}$ & \\
\hline 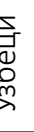 & 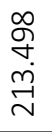 & $m^{m}$ & 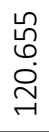 & $\stackrel{\circ}{\sim}$ & $\begin{array}{l}\stackrel{?}{N} \\
\tilde{\omega} \\
\dot{n} \\
\stackrel{n}{\sim}\end{array}$ & $\stackrel{\text { I }}{\sim}$ & 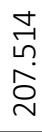 & $\stackrel{6}{-i}$ & 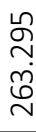 & & & & & $\stackrel{\text { In }}{\sim}$ & 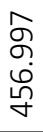 & $\stackrel{\text { q }}{\sim}$ & \\
\hline$\frac{5}{2}$ & 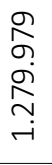 & बे & $\begin{array}{l}\hat{\infty} \\
\emptyset \\
\infty \\
\omega_{0} \\
\sim \\
\sim\end{array}$ & $\begin{array}{l}\circ \\
\text { ó } \\
\text { q }\end{array}$ & 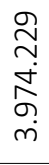 & ণ্ & 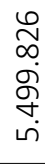 & $\stackrel{\infty}{\stackrel{\infty}{\sim}}$ & $\begin{array}{l}\text { 오 } \\
\text { Nે} \\
\text { مे } \\
\text { ஸे }\end{array}$ & & & & & $\begin{array}{l}\text { बे } \\
\text { থे }\end{array}$ & 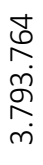 & $\stackrel{\sim}{\sim}$ & \\
\hline 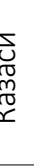 & 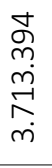 & 공 & 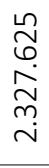 & $\stackrel{\infty}{\stackrel{\infty}{m}}$ & 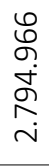 & $\begin{array}{l}\circ \\
\text { ○' }\end{array}$ & $\begin{array}{l}\vec{b} \\
\underset{-1}{-1} \\
\underset{\sim}{\sim} \\
+\end{array}$ & $\stackrel{+}{\sim}$ & 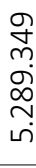 & & & & & 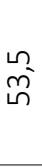 & 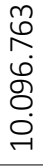 & तु & \\
\hline & $\begin{array}{l}\overline{0} \\
\text { ம}\end{array}$ & dᄋ & $\begin{array}{l}\overline{8} \\
\text { 믐 }\end{array}$ & வீ & $\begin{array}{l}\overline{8} \\
\text { 음 }\end{array}$ & $\alpha^{\circ}$ & 음 & ১ீ & 음 & $\alpha$ & & & & ১̊ & 吕 & வீ & \\
\hline & 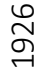 & & $\begin{array}{l}\text { } \\
\text { مे }\end{array}$ & & 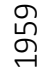 & & $\begin{array}{l}\text { 윽 } \\
\text { 익 }\end{array}$ & & న & & & & & & ஓి & & \\
\hline
\end{tabular}


После Другог светског рата и обнове СССР-а, у периоду 1953-1965. у казахстанским степама реализован је хрушчовски програм освајања ледина, раније коришћених као пашњаци. Овај процес оцењен је касније као погрешан, па чак и штетан. Поред економских он је имао и значајне друге аспекте и последице. Као што се може видети у табели 1, број и удео неказашких народа, пре свега Руса, у пописима 1959. и 1970. значајно је увећан, тако да су у 1970. и касније 1979. (и поред мањег смањења удела) Руси чинили релативну већину становништва у Казахстану. За земљу која је већ дуго била двонационална (са још много припадника других народа), овакав прилив становника других националности може у културном смислу имати и позитивне ефекте, али свакако доноси (или бар - крије у себи) и друге могуће последице. Пошто се управо у другој половини 20. века завршио процес образовања казашке управљачке елите, отпочео је и процес истискивања неказаха с руководећих места, а представници носеће нације почели су да заузимају високе дужности у привреди, образовању, култури. Овоме је посебно енергично допринео штићеник Л. Брежњева Динмухамед Ахмедович Кунајев, први секретар ЦК Компартии Казахске ССР (1960-1962, 1964-1986), односно фактички руководилац Казахстана у тим годинама. ${ }^{36}$ На тај начин, могло би се рећи да је заправо обновљен процес коренизације из времена после Октобарске револуције па све негде до краја 1930-их година. А он ће након стицања независности само добијати на убрзању.

\section{Казахизација}

После стицања независности у Казахстану се спроводи политика која је добила популаран назив казахизација. Кратко речено, реч је о национално-културном процесу у коме се са највишег, државног врха афирмише национална културна политика и национални - казашки језик. Велику пажњу овај процес изазива најпре посматран у уском смислу узајамног односа двеју водећих националних заједница у Казахстану и проблема билингвализма. Наравно, ово није нимало чудно будући да је после проглашења независности наступио период изузетно интензивног

\footnotetext{
${ }^{36}$ Большая актуальная политическая энциклопедия, Москва: Эксмо, 2009, стр. 119.
} 
емигрирања руских житеља Казахстана. О томе је било речи и у литератури на српском језику. ${ }^{37}$ Погледајмо, дакле, податке који се односе на период 1993-2003: 1993. прешло је (или чак пребегло) у Русију 170.129 људи руске националности; године 1994 - 283.154; 1995 - 160.883; 1996 -120.427; 1997 - 174.616; 1998 - 186.397; 1999 - 89.998; 2000 - 109.343; 2001 - 100.000; 2002 - 70.000; 2003 - 36.800. Овакав егзодус руског становништва свакако је нешто што заслужује посебну пажњу и анализу. У Великој актуелној политичкој енциклопедији наводи се да је интензивна емиграција у годинама 1990-1998. (до 400.000 годишње) довела до великог смањења удела недомаћег у укупном становништву, али се констатује да дискриминација Руса и русофобија у Казахстану никада није имала такве размере као у другим републикама бившег СССР-а. ${ }^{38}$ Оваква оцена већ на први поглед противречна је, како с наведеним подацима (можда у мањој мери), тако и с оценом која је дата у поменутом раду 3. Милошевића, што се види и из самог његовог назива. Милошевић констатује да се Казахстан по стицању независности „бавио унутрашњим проблемима и стварањем сопствене националне државе“, али да тај процес „није баш сасвим имао цивилизоване облике и садржаје“, да је укључивао и претњу геноцидом, и да је наносио штету међудржавним и међунационалним односима Русије и Казахстана. ${ }^{39}$

Политика приоритета титуларне (домаће) нације односи се на све сфере живота, али је можда најизраженија у језичкој политици. Државна

${ }^{37}$ Видети: 3. Милошевић, Прогон Руса из Казахстана, Српска политичка мисао, 2006, № 3-4, стр. 92. и Д. Петровић, Демографска ситуација савременог Казахстана, Демографрија, год. 8, 2011, стр. 214. Они заправо наводе податке из текста Донаке О’Бичејн, уз констатацију да се интензитет тог исељавања смањује. Међутим, за извођење оваквог закључка (или његово оповргавање) коректније је разматрати не апсолутне бројеве емиграната, већ удео тих бројева у укупном становништву Казахстана руске националности, које се наравно драматично смањује управо због тог исељавања. Ми се тиме нећемо посебно бавити, не само због недостатка детаљних подата за касније године (па и године од 1990, када је емиграција започела), већ пре свега зато што такве циљеве и нисмо поставили.

${ }^{38}$ Большая актуальная политическая энциклопедия, Москва: Эксмо, 2009, стр. 119. Из података који су овде наведени следило би да је број исељених Руса у годинама 1990-1992. био и већи него касније.

39 3. Милошевић, Прогон Руса из Казахстана, Српска политичка мисао, 2006, № 3-4, стр. 90-91. 
језичка политика која се спроводи у Казахстану третира се од стране домаћих политичара и других као усклађена с Уставом Републике Казахстан, Законом „О языках в Республике Казахстан“ от 11 июля 1997 года, као и Државним програмом функционисања и развоја језика за године 2001-2010, утврђеним Указом Председника РК од 7. фебруара 2001. године №550. Стратегија програма функционисања и развоја језика одредила је достизање три основна циља: проширење и учвршћење социјално-комуникативних функција државног казашког језика; очување општекултурних функција руског језика; развитак језика етничких група. ${ }^{40}$

Ситуација у погледу билингвизма према, резултатима Пописа 1999, приказана је у табели 2, која представља део табеле приложене у изворном раду. Одабрали смо наиме само крупније националности.

Табела 2: Владање језиком своје националности, казашким и руским основних националности у Казахстану. Попис становништва 1999.

\begin{tabular}{|c|c|c|c|c|c|c|c|c|}
\hline \multirow{2}{*}{$\begin{array}{c}\text { Основне } \\
\text { национал- } \\
\text { ности }\end{array}$} & \multirow[b]{2}{*}{$\begin{array}{c}\text { Укупно } \\
\text { становништво }\end{array}$} & & \multicolumn{6}{|c|}{ Владају језиком } \\
\hline & & & $\begin{array}{c}\text { своје } \\
\text { национал } \\
\text { ности }\end{array}$ & & казашким & & руским & \\
\hline Свега & 14.953 .126 & & 13.483 .029 & & 1.697 .682 & & 8.193.866 & \\
\hline Казаси & 7.985.039 & 100,0 & 7.933 .627 & 99,4 & & & 5.988 .532 & 75,0 \\
\hline Руси & 4.479 .620 & 100,0 & 4.479 .527 & 100,0 & 666.499 & 14,9 & & \\
\hline Азербејџанци & 78.295 & 100,0 & 39.191 & 50,1 & 49.630 & 63,4 & 67.368 & 86,0 \\
\hline Јермени & 14.758 & 100,0 & 6.700 & 45,4 & 3.224 & 21,8 & 14.382 & 97,5 \\
\hline Башкири & 23.225 & 100,0 & 6.540 & 28,2 & 13.532 & 58,3 & 22.731 & 97,9 \\
\hline Белоруси & 111.927 & 100,0 & 15.142 & 13,5 & 11.081 & 9,9 & 111.213 & 99,4 \\
\hline Немци & 353.441 & 100,0 & 77.204 & 21,8 & 54.604 & 15,4 & 351.091 & 99,3 \\
\hline Пољаци & 47.297 & 100,0 & 4.304 & 9,1 & 4.666 & 9,9 & 46.779 & 98,9 \\
\hline Татари & 248.954 & 100,0 & 92.457 & 37,1 & 158.310 & 63,6 & 241.250 & 96,9 \\
\hline
\end{tabular}

Извор: О. Б. Алтынбекова, Миграция в Казахстане: новый статус русского языка

${ }^{40}$ О. Б. Алтынбекова, Миграция в Казахстане: новый статус русского языка. 
Као што се види, у оквиру крупних дијаспора руским језиком владало је 86\% Азербејџанаца, 99,4\% Белоруса, 97,5\% Јермена, 97,9\% Башкира, 99,3\% Немаца, 98,9\% Пољака, 96,9\% Татара, затим 97,7\% Корејаца, 76,9\% Курда, 75,9\% Турака, 59,2\% Узбека, 76,1\% Ујгура, 99,5\% Украјинаца, 94,1\% Чечена. Проценат људи разних националности који владају руским језиком веома је висок, уз изузетак Таџика, који су немного пре Пописа имигрирали у Казахстан. Релативно ниски проценат владања руским језиком постоји и међу Узбецима који живе пре свега у Јужно-Казахстанској области, која се граничи са Узбекистаном, где њихов број чини 89,6\% од укупне бројности дијаспоре. Наравно, с обзиром на велико исељавање пре свега становништва руске националности после 1999, и промене националне структуре, дошло је и до промена у језичкој ситуацији (видети стање по Попису 2009, табела 3). И поред значајно измењене етничке ситуације, подаци из ове табеле показују да је двојезичност и даље доминантна слика језичке ситуације у Казахстану. И не само то, иако је удео руског становништва сведен на мање од једне петине, руски језик је у целини и даље заступљенији од казашког.

Табела 3: Становништво (узраста 15 година и више) по националности и степену владања казашким и руским језиком у Казахстану. Попис становништва 2009.

\begin{tabular}{|c|c|c|c|c|c|}
\hline \multirow{2}{*}{ Националност } & \multirow{2}{*}{ Укупно } & \multicolumn{2}{|c|}{ Казашки језик } & \multicolumn{2}{c|}{ Руски језик } \\
\cline { 3 - 6 } & усмено & $\begin{array}{c}\text { читају } \\
\text { и пишу }\end{array}$ & усмено & $\begin{array}{c}\text { читају } \\
\text { и пишу }\end{array}$ \\
\hline Свега & 12.150 .912 & 8.988 .520 & 7.528 .543 & 11.467 .426 & 10.306 .797 \\
\hline Казаси & 7.316 .271 & 7.195 .842 & 6.817 .519 & 6.735 .892 & 5.788 .758 \\
\hline Руси & 3.182 .349 & 806.169 & 200.017 & 3.133 .266 & 3.078 .668 \\
\hline Узбеци & 307.718 & 293.892 & 189.881 & 285.934 & 210.107 \\
\hline Украјинци & 299.312 & 64.284 & 15.574 & 295.962 & 290.560 \\
\hline Ујгури & 166.175 & 155.774 & 101.024 & 159.214 & 135.996 \\
\hline Татари & 173.885 & 126.187 & 58.552 & 171.144 & 164.677 \\
\hline Немци & 146.624 & 36.258 & 11.596 & 145.148 & 142.030 \\
\hline Корејци & 81.720 & 35.513 & 8.578 & 80.084 & 78.046 \\
\hline
\end{tabular}




\begin{tabular}{|c|c|c|c|c|c|}
\hline \multirow{2}{*}{ Националност } & \multirow{2}{*}{ Укупно } & \multicolumn{2}{|c|}{ Казашки језик } & \multicolumn{2}{|c|}{ Руски језик } \\
\cline { 3 - 6 } & усмено & $\begin{array}{c}\text { читају } \\
\text { и пишу }\end{array}$ & усмено & $\begin{array}{c}\text { читају } \\
\text { и пишу }\end{array}$ \\
\hline Турци & 69.616 & 63.332 & 30.219 & 66.898 & 58.247 \\
\hline Азербејџанци & 62.876 & 51.090 & 27.190 & 60.916 & 53.722 \\
\hline Белоруси & 60.017 & 11.377 & 2.906 & 59.346 & 58.187 \\
\hline Дунгани & 32.202 & 16.017 & 5.163 & 31.570 & 29.881 \\
\hline Остали & 252.147 & 132.785 & 60.324 & 242.052 & 217.918 \\
\hline
\end{tabular}

Извор: Перепись населения Республики Казахстан 2009 года. Краткие итоги, Астана: Агентство Республики Казахстан по статистике, 2010.

У званичном наративу који смо већ поменули, језичка слика је, ипак, и даље прилично идеализована. Реализација програма функционисања и развоја језика, према њему, претпоставља стварање оптималног социолингвистичког простора у земљи, који је одређен достизањем потребног функционалног суодноса језика, коришћених на территорији Казахстана. То условљава практичну реализацију државног статуса казашког језика, остваривање законодавно утврђених њихових социјалних функција на целој територији републике у свим сферама друштвених односа, као и очување основних функција руског језика у пуном обиму, које му гарантује Устав РК: он остаје језик официјелно коришћен у државним организација и органима локалне самоуправе, обезбеђује се његово функционисање у области образовања, науке, културе и других друштвено значајних сфера. ${ }^{41}$

Насупрот овој, у доброј мери идиличној, слици налазе се многе оцене другачијег, или чак потпуно супротног карактера. Тако, 3. Милошевић у поменутом тексту говори о очигледном прогону руског језика из државне управе, медија, културе и образовања, иако према службеним подацима овај језик представља матерњи или први језик за 80\% становника Казахстана, као и протеривање руског језика из медија и забрана реемитовања руских сателитских радио и телевизијских емисија, и од 1991. године забрана продаје штампе из Русије. ${ }^{42}$

41 О. Б. Алтынбекова, Миграция в Казахстане: новый статус русского языка.

42 3. Милошевић, Прогон Руса из Казахстана, Српска политичка мисао, 2006, № 3-4, стр. 93, 94. Према новијим подацима које наводи Д. Верхотуров (Д. Верхотуров, 
Један од показатеља суштине казахизације свакако је латинизација казашког алфабета. Одговарајући Указ потписао је председник Казахстана 2017. године, али су припреме, како формалне тако и припреме јавног мњења, трајале већ цели низ година. Планирано је да се тај прелаз оствари до 2025. године. Иако није никаква новост на просторима Средње Азије, ${ }^{43}$, па чак како смо видели ни широм Совјетског Савеза у 1920-им годинама, она је за процес који разматрамо новији захтев, покренут са државног врха. Ако се и може разумети жеља званичника да казашки језик добије већи значај, а што ће се наравно у будућности свакако и десити, прелазак на латинску графику је нешто што може да изазове само чуђење. У најмању руку. Посебно ако се има у виду да је ово већ трећа смена писма казашког језика у току мање од једног века. ${ }^{44}$ Само по себи то представља велики проблем за писменост једног народа, чак и у случају када би се овим прелазима ишло од лошијег ка бољем алфабету. А то је ствар која је оспоравана и која се и данас оспорава и у круговима водећих интелектуалаца у самом Казахстану, као што је то био случај и у периоду

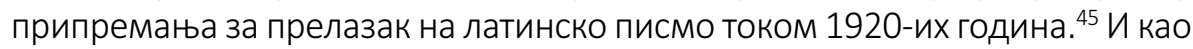

Казахизация Казахстана: модели и прогнозы, Столетие, 22.01.2021.) и поред масовног егзодуса руског становништва по официјелним подацима за 2018. годину, удео становништва које влада руским језиком износио је 92,3\%.

${ }^{43}$ Непосредно по распаду СССР-а на латиницу је прва прешла Туркменија, а после неколико година то су урадили и Узбекистан и Киргизија. Сва три покушаја, међутим, оцењују се у основи негативно, као неуспели и као пројекти који су уз велике трошкове и напоре дали крајње мале резултате.

44 Прво писмо којим су се користили казаси - древнотуркијско (или орхонско, тј. орхонско-јенисејско), припада далекој прошлости. Њему је на смену дошло арапско, којим су се користили око хиљаду година, да би крајем 1920-их био извршен прелаз на латиницу, а после само десет година на ћирилицу. (М. Джусупов, Письмо - язык в графике (казахская письменность во временном и географическом пространстве), Вестник РУДН, серия Теория языка. Семиотика. Семантика, 2011, № 4, с. 22).

45 Главни опонент тадашњих „латиниста“ био је „арабист“ Ахмет Бајтурсинов, аутор научно заснованог казашког писма (реформисано арапско писмо) на основи арапске графике, које су користили у Казахстану и сви Казаси у дијаспори, затим Каракалпакстан, Киргизстан од 1913. до 1929. године, на ком су издаване новине, часописи, књиге, уџбеници итд., и које и данас примењује казашка дијаспора, на пример у Кини. (М. Джусупов, Письмо - язык в графике (казахская письменность во временном и географическом пространстве), Вестник РУДН, серия Теория языка. Семиотика. Семантика, 2011, № 4, с. 29; Г. Каратаева, Из истории казахского алфавита: арабская графика - латиница - кириллица.) 
што тада, под државном силом, нису уважавани одговарајући аргументи, ${ }^{46}$ нема сумње да се ни данас неће десити исто. И да се неће остварити намеравани прелазак на латиничко писмо. Али, друго је питање да ли ће се и колико ће се то писмо задржати.

Као што је својевремено истицао Бајтурсинов, тако се и данас појављују мишљења која доказују да нису тачни аргументи којима се правда прелаз на латинско писмо. Тако Мурат Ауезов сматра да је латинско писмо веома лако, да ће се на њој писати лакше него на ћирилици, да је латиница веома једноставна итд. ${ }^{47}$ Ове „аргументе“ општег типа веома је лако оспорити, као што то рецимо чини Махамбет Џусупов, истичући да су унутрашње, иманентне могућности латинског писма веома ограничене, што је резултат чињенице да се оно није транспормисало и прилагођавало језицима оних народа који су га прихватали. Стога је и у енглеском, данас најраширенијем у оквиру језика који користе латиницу, остао проблем великог раскорака између броја гласова и броја слова - у енглеском јазику је 46 фонема, а у алфабету 26 знакова. Ако се овај факт посматра с позиције монографа (једна фонема - једно слово), онда недостаје чак 20 слова, а то је веома много за било који језик. Проблеми тог типа морају се решавати ортографским путем, а то са своје стране усложњава саму ортографију. У том смислу казашки ћирилички алфабет са 42 знака (слова) има знатно веће могућности него латински, а то би био случај и када би се постојећи диграфи (я, ю, ё) заменили одговарајућим комбинацијама (на пример, ја, ју, јо, дакле прихватањем јоте). Тиме би се могао смањити број слова а да се не утиче на ортографију. У сваком случају унутрашње могућности ћириличке графике за превођење на писмо фонема овог или оног језика веће су него код латинице. ${ }^{48}$

\footnotetext{
${ }^{46}$ Бајтурсинов је истицао: „Ми, Казаки (тако су се тада називали -Р. Б.), давно смо одредили основне елементе својег говора, означивши их одговарајућим знацима, пишемо добро, читамо добро, усвајамо писменост знатно лакше и брже, него Руси, Немци, Французи, Енглези и други. И шта нам још треба? Не, говоре, нужно нам је да променимо своје писмо латинским, зато што наше писмо није наше - арапско је.... " (Г. Каратаева, Из истории казахского алфавита: арабская графика - латиница - кириллица.) Дакле, Бајтурсинов је тада указивао пре свега на политички, а не научни моменат, и наравно и критиковао га.

${ }^{47}$ М. Ауэзов, Язык - всему голова. Переход казахской письменности с кириллицы на латиницу вызывает много споров, Литер.

${ }^{48}$ М. Джусупов, Письмо - язык в графике (казахская письменность во временном и географическом пространстве), Вестник РУДН, серия Теория языка. Семиотика. Семантика, 2011, № 4, с. 23. и даље.
} 
У наведеном раду Џусупов се дотиче и проблема писма којим ће се користити казашка дијаспора у другим земљама, као и изузетно важног питања до сада накупљеног културног и научног наслеђа на ћириличком писму, на ком је објављено више од 90\% целокупне штампане продукције на казашком језику. Најзад, сам прелаз на латиницу, са знатно сложенијом ортографијом неминовно ће довести до опадања фактичке писмености целокупног становништва, што се у време огромне продукције писане речи никако не сме заборавити.

Присталице преласка на латиницу, попут поменутог Ауезова, истичу и још један аргумент: унификација писма за туркијске народе, који су већ прешли на латиницу или убрзано на томе раде, као што су Туркменистан, Турска, Узбекистан, Киргистан, Азербејџан, Татарстан. Не улазећи у то да ли је овај аргумент коректан (барем када је реч о Татарстану, па и Башкирији која се ту и не помиње), ${ }^{49}$ може се констатовати да се поново са лингвистичког поља проблем пребацује на политичко. А ако би се остварио мало дубљи увид у проблематику Средње Азије и њеног геополитичког и геостратешког положаја и значаја, могло би се закључити да се заправо овде ради о геополитичким интересима САД и њених савезника, који покушавају да овај простор извуку из интересне сфере пре свега Русије, односно да се "уклине“ између Русије, Ирана и Кине, земаља које су све суштински главни противници Америке, каквима су и означене у Националној стратегији безбедности САД. ${ }^{50}$

\section{Закључак}

Заигравање са националистичким (тачније - шовинистичким) снагама не може никада да се заврши добро. У Казахстану се већ годинама прогањају они који су за добросуседске односе са Русијом (или чак за уједињење), као што показују примери најпознатијег међу таквима,

\footnotetext{
49 У Туркменији и Узбекистану, које су прве оствариле овај прелаз још почетком 1990-их, реформе су реализоване половично, резултовале су значајним проблемима и тренутно су њихове перспективе неизвесне. Што се тиче Татарстана и Башкирије, проблем је пре у Руској Федерацији него у њима самима, тако да бар по садашњем стању ствари о томе и нема речи.

${ }^{50}$ А. Пахолин, Латиница в Центральной Азии - инструмент геополитики США.
} 
Јермека Тајчибекова, који је већ био у затвору због својих ставова о проблему Голодомора (такозваног ашаршлыка) 1930-их у Казахстану, о потреби уједињења са Русијом и сл., а осуђен је због наводног распиривања националне мржње између Казаха и Руса (сиц!). ${ }^{51}$

Управо погром над Дунганима, ${ }^{52}$ националном заједницом која ни у ком случају не би могла представљати било какву претњу Казасима (нити било којој другој заједници у Казахстану), са уделом од свега 0,40\% у укупном становништву Казахстана, показује сву лудост али уједно и опасност од оваквих снага. У фебруару 2020. године у Жамбилској области на југу Казахстана у организованом погрому убијено је 11 Дунгана, десетине кућа је спаљено, уништено је много имовине. Више од 23 хиљаде Дунгана побегло је у суседни Киргистан, неколико хиљада се посакривало у џамијама у Казахстану. И Јермеку Тајчибекову, који је јавно осудио погром дунганске националне мањине, организује се суђење због наводног распиривања националне нетрпељивости и мржње! А за петоро Дунгана који су пружили отпор казашким шовинистима државни тужилац је затражио казне од 15 до 18 година!

Као један од кључних момената актуелног процеса казахизације испоставља се прелаз на латиницу. Он ће сигурно допринети продубљивању подела и сукобљавања и у оквирима самих Казаха, како у Казахстану тако и у казашкој дијаспори, и то потпуно независно од могућих наведених сукоба са унутрашњом дијаспором, попут поменутог са Дунганима. Наравно, нико не може и не треба да спори суверено право казашком народу и његовој власти да и ова питања уређује како нађе за сходно (тим пре ако власт има подршку сопственог народа). Али, исто тако не може се спорити ни право сагледавања и анализирања тих процеса и њихових последица, које се сигурно не могу задржати само у оквирима Казахстана.

\footnotetext{
${ }^{51}$ Видети: Казахстан ведут по украинскому сценарию русофобии. Пошто је већ одлежао затворску казну, Тајчибекову се поново суди (видети: А. Курманов, Казахстан репрессиями зачищают от сторонников объединения с Россией), опет за распиривање међунационалне мржње, иако је овог пута он иступио против националиста (шовиниста) који су приредили крвави погром Дунгана на југу земље у фебруару 2020.

52 Видети: Кто такие дунгане и почему у них проблемы с казахами?, Живая Средняя Азия.
} 


\section{Литература}

Алексеенко, Николай Владимирович, Население дореволючионного Казахстана (численность, размещение, состав, 1870-1914 г2.), АлмаАта: Издательство «Наука» Казахской ССР, 1981.

Аманжолова, Кульназия Бодиховна, Проблемы казахско-русского двуязычия и их интерпретация в трудах современных лингвистов, Ученые записки Новгородского государственного университета имени Ярослава Мудрого, 2019, № 7 (25), с. 1-4.

Бартольд, Василий Владимирович, Киргизы (исторический очерк), Фрунзе: Киргосиздат, 1927.

Большая актуальная политическая энциклопедия, Москва: Эксмо, 2009.

Буквич, Райко М., От политики к лингвистике и обратно: языковая проблема на Украине, у: Говор мржње и култура памћења, прир. Зоран Милошевић и Милош Кнежевић, Београд: Институт за политичке студије, 2020, стр. 315-346.

Двенадиатый съезд РКП(б). Стенографический отчёт, Москва: Политиздат, 1968.

Джусупов, Маханбет, Письмо - язык в графике (казахская письменность во временном и географическом пространстве), Вестник РуДН, серия Теория языка. Семиотика. Семантика, 2011, № 4, с. 22-31.

Закиева, Шынар Болатовна, Интеграция в Центральной Азии и Казахстан, Москва: Научная книга, 2007.

Закон «О языках в Республике Казахстан» от 11 июля 1997 г.

Келльнер-Хайнкеле, Барбара, и Ландау, Якоб М., Языковая политика в современной Центральной Азии: начиональная и этническая идентичность и советское наследие. Москва: Центр книги Рудомино, 2015.

Кюстин, Астольф де, Николаевская Россия, Москва: Политиздат, 1990.

Ленин, Владимир Ильич, К вопросу о национальной политике, Полное собрание сочинений, Том 25, Москва: Издательство политической литературы, 1980, с. 64-72. 
Ленин, Владимир Ильич. О праве наций на самоопределение, Полное собрание сочинений, Том 25, Москва: Издательство политической литературы, 1980, с. 255-320.

Лю, Сяньчжун, Плюсы и минусы политики «коренизации» СССР в 1920 е годы, Ойкумена, 2014, № 1, с. 41-49.

Мартин, Терри, Империя «положительной деятельности». Нации и национализм в СССР, 1923-1939, Москва: РОССПЭН и Фонд «Президентский центр Б. Н. Ельцина», 2011.

Милошевић, Зоран, Прогон Руса из Казахстана, Српска политичка мисао (Београд), 2006, № 3-4, стр. 89-100.

Михайлова, Наталья Вячеславовна, и Вячеслав Александрович Михайлов, Была ли царская Россия «тюрьмой народов»?, Свободная мысль, 2013, № 6, с. 143-162.

Перепись населения Республики Казахстан 2009 года. Краткие итоги, Астана: Агентство Республики Казахстан по статистике, 2010.

Петровић, Драган, Геополитика постсовјетског простора, Нови Сад: Прометеј и Београд: Институт за међународну политику и привреду, Нови Сад, 2008.

Петровић, Драган, Демографска ситуација савременог Казахстана, Демографија, година 8, 2011, стр. 211-221.

Петровић, Драган и Рајко Буквић, Казахстан као чинилац интеграционих процеса на постсовјетском простору, Интеграциони процеси у Евроазији, Београд: Институт за међународну политику и привреду, 2019, стр. 191-213.

Советский Союз. Республики Закавказья. Республики Средней Азии. Казахстан, отв. ред. Т. А. Жданко, (Страны и народы. Издание в 20-ти томах), Москва: Мысль, 1984.

«Средняя Азия и Центральная Азия», у: Географический энциклопедический словарь: Географические названия, 3-е изд., гл. Ред. В. М. Котляков, Москва: Большая Российская энциклопедия, 2003.

Тархов, Сергей. Изменение административно-территориального деления России в XIII-XX вв., Логос, 2005, № 1 (46), с. 65-101.

Томсинов, Владимир Алексеевич, Сперанский, Москва: Молодая гвардия, 2006. 


\section{Интернет извори}

Алтынбекова, Ольга Баймухановна, Миграция в Казахстане: новый статус русского языка, Демоскоn Weekly, № 251-252, 19 июня - 20 августа 2006, http://www.demoscope.ru/weekly/2006/0251/analit05.php (приступ остварен 19. маја 2021).

Ауэзов, Мурат, Язык - всему голова. Переход казахской письменности с кириллицы на латиницу вызывает много споров, Литер, 02.12.2008. https://centrasia.org/newsA.php?st=1228253400 (приступ остварен 30. мaja 2021).

Буквић, Рајко, Совјетски пројекат латинизације руског алфабета, Нова српска политичка мисао, 24. август 2013. (Доступно на: http://ssrn.com/ abstract $=2919360$ )

Варыханов, Станислав, Общее прошлое и общее будущее, Комсомольская правда, 21 апреля 2021, https://www.kp.ru/daily/27268.4/4402169/ (приступ остварен 15. маја 2021).

Верхотуров, Дмитрий, Казахизация Казахстана: модели и прогнозы, Столетие, 22.01.2021. https://www.stoletie.ru/vzglyad/kazahizacija_kazahstana_ modeli_i_prognozy_696.htm (приступ остварен 17. маја 2021).

Европейское население в Казахстане в 2020 году, https://yandex.ru/ images/search?text=eвропейское\%20население\%20в\%20казахстане\&sty pe=image\& $\mid r=10522 \&$ source=wiz\&pos=0\&img_url=https\%3A\%2F\%2Fuploa d.wikimedia.org\%2Fwikipedia\%2Fcommons\%2Fthumb\%2F6\%2F6c\%2FKaza khstan_European_Rus.png\%2F1000px-Kazakhstan_European_Rus.png \&rpt=simage

Земельно-водные реформы, Большая российская энциклопедия электронная версия, 2004. https://bigenc.ru/geography/text/2032993

Казахстан ведут по украинскому сценарию русофобии, 22 октября 2017, http://новости-казахстана.ru-an.info/новости/казахстан-ведут-поукраинскому-сценарию-русофобии/ (приступ остварен 20. марта 2021).

Казахстан, Большая российская энциклопедия - электронная версия, 2004. https://bigenc.ru/geography/text/2032993

Как присоединялся Казахстан к России на самом деле? - Султанов, ИАЦентр, 27 декабря 2017, https://ia-centr-ru.turbopages.org/ia-centr.ru/s/ 
publications/kak-prisoedinyalsya-kazakhstan-k-rossii-na-samom-delesultanov/ (приступ остварен 22. маја 2021).

Каратаева, Гульнар, Из истории казахского алфавита: арабская графика латиница - кириллица, https://tengrinews.kz/article/istorii-kazahskogoalfavita-arabskaya-grafika-latinitsa-639/ (приступ остварен 12. марта 2021).

Конституция Республики Казахстан 1995, с изменениями 1998, 2007, 2011, 2017 и 2019 гг. https://adilet.zan.kz/rus/docs/K950001000_ (приступ остварен 20. маја 2021.)

Кто такие дунгане и почему у них проблемы с казахами?, 10 февраля 2020, Живая Средняя Азия, https://zen.yandex.ru/media/centralasia/kto-takiedungane-i-pochemu-u-nih-problemy-s-kazahami-5e40efe23cf0eb04dcde 1886 (приступ остварен 23. априла 2021).

Курманов, Айнур, Казахстан репрессиями зачищают от сторонников объединения с Россией, 23.04.2021, https://www.politnavigator.news/ kazakhstan-repressiyami-zachishhayut-ot-storonnikov-obedineniya-srossiejj.html (приступ остварен 23. априла 2021).

Население Казахстана и статистическая информация, https://rosinfostat.ru/ naselenie-kazahstana-i-statisticheskaya-informatsiya/ (приступ остварен 17. маја 2021).

Национальный состав населения по республикам CCCP, http://www.demo scope.ru/weekly (приступ остварен 25 маја 2021).

Пахолин, Алексей, Латиница в Центральной Азии - инструмент геополитики СШA, https://www.fondsk.ru/news/2019/02/05/latinica-v-centralnoj-aziiinstrument-geopolitiki-ssha-47553.html (приступ остварен 20. маја 2021).

Речь пойдёт о истории ПОЯВЛЕНИЯ государства “Казахстан" и т.н. "казахов"..., https://Isvsx.livejournal.com/778925.html (приступ остварен 26. фебруара 2021).

Численность населения Республики Казахстан по отдельным этносам на начало 2021 года. Комитет по статистике Министерства национальной экономики Республики Казахстан. (приступ остварен 20. маја 2021). 


\title{
FROM KORENIZATION TO KAZAKHIZATION: SEARCH FOR NATIONAL IDENTITY OR INTRODUCTION TO NEW CONFLICTS
}

\begin{abstract}
The paper considers the current ethnic and language situation in Kazakhstan, the greatest land in the Middle Asia space and a key Russian partner and participant in all integration processes of the post-soviet space. For more than two centuries in the Russian Empire, Kazakhstan developed as a multiethnic and bilingual society. Based on short historical observation, it was remarked on the analogy between the processes of korenization during the 1920s and 1930s, when Kazakhstan acquired its duties of state in the USSR, and the process of kazakhization after the collapse of the USSR, and during his whole independence. It was emphasized that the process of the national identity search in the framework of the reliance of the nationalistic (chauvinistic) forces led to the conflicts in Kazakhstan, as was demonstrated through massacres of the Dungan national minority. As a specific aspect of the kazakhization process, it was emphasized the planned shift of the Kazakh language to the Latin alphabet. This will surely cause many aftermaths, among them also negative. Behind this process, in the last instance, are not linguistical but political, i.e., geopolitical reasons. This also leads to possible new conflicts in Kazakhstan, as well as abroad, in the spaces of Middle Asia that are of special importance for the US and their allies.
\end{abstract}

Keywords. korenization, kazakhization, Kazakhstan, multiethnicity, bilingualism, national identity, conflicts, chauvinism. 